\title{
Modelling the critical concentration of mixed filler in mastic with synthetic wax
}

\author{
Grzegorz Mazurek ${ }^{1, *}$ and Marek Iwański $^{1}$
}

${ }^{1}$ Kielce University of Technology, Faculty of Civil Engineering and Architecture, Al. Tysiąclecia Państwa Polskiego 7, Poland

\begin{abstract}
This article presents the results of tests of mastic containing mixed filler (limestone dust/hydrated lime) and Fisher-Tropsch synthetic wax. Synthetic wax content was controlled up to $3 \%$ $(\mathrm{w} / \mathrm{w})$. The ratio of filler in the bitumen was from 0.5 to $3(\mathrm{w} / \mathrm{w})$, with hydrated lime content of up to $30 \%$ $\mathrm{w} / \mathrm{w}$. The rheological properties of different mastic compositions were determined with a rheometer equipped with two parallel plates at $60^{\circ} \mathrm{C}$ using oscillating load. The primary purpose of the article was to determine the nature of mastic stiffness changes in the context of using hydrated lime and synthetic wax as the filler. Consequently, the article proposes a method for evaluation of the critical value of the filler phase in the phase of bitumen modified with synthetic wax. The proposed model of the mathematical function was used to determine the nature of mastic structuring throughout the range of the experiment. The model was also used to determine the critical concentration of the filler in the bitumen phase. It was demonstrated that below the critical filler concentration the mastic behaved in a significantly different manner from the behaviour observed above this critical concentration. When the critical concentration of the filler was exceeded, it resulted in an excessive increase of mastic stiffness, which was considered in the model.
\end{abstract}

\section{Introduction}

Asphalt mastic is a suspension of filler in asphalt that coats coarse grains in asphalt mixture [1]. Mastic is the correct binder in the asphalt mixture, playing a key role in the compaction of asphalt mixtures, and it also affects their durability throughout their service life [2], [3]. The stiffening effect on asphalt caused by the mineral filler content affects the mechanical properties of asphalt mixtures in terms of resistance to permanent deformation and low temperatures [4], [5]. On the basis of Polish experience the beneficial influence of hydrated lime on visco-elastic properties of bituminous mixtures was also confirmed [6]. The structuring function of the filler in the mastic depends on multiple parameters, including filler type, grain size distribution and filler concentration in the mastic [7]. With low filler concentration, the mastic is in a diluted state, and the nature of mastic structuring by the filler depends on the volume of the filler in the mastic and the physical and chemical synergy between the bitumen and the filler. However, after the critical concentration of the filler in the mastic was exceeded, the increase of mastic stiffness was also affected by the interaction between filler particles [8]. A suitable amount of filler particles dispersed in the asphalt slow down crack propagation in mastics due to the "pinning" effect [9]. According to Miro et al. [10], excessive filler amount may increase the brittleness of the mastic and impair its properties at low temperatures. In the extensive paper [7], it was found that the content of filler in the form of hydrated lime at low temperature did not cause a further increase of mastic stiffness due to the presence of the filler. Hydrated lime, owing to its basic reaction, successfully impacts asphalt properties [11] and improves asphalt adhesion to the aggregate with high $\mathrm{SiO}_{2}$ silica content. It also acts as an asphalt antioxidant, slowing down asphalt ageing and, consequently, the loss of visco-elastic properties [12].
Hydrated lime also causes a larger increase of mastic stiffness than the filler normally added to the bitumen, which is particularly important at high working temperatures [7], [13]. There has been no observed negative impact of hydrated lime on the increased rate of temperature-induced cracks. The presence of an active filler increases the stiffness of the mastic and improves resistance to permanent deformation of the asphalt mixture, increasing the fatigue life and loading time sensitivity [14]. The key issue is to separate the function of the filler $(\mathrm{d}<0.075 \mathrm{~mm})$ of coarse aggregate fractions in the asphalt mixture. The filler suspension in the bitumen fills the voids between coarse grains of the asphalt mixture [15]. Consequently, the amount of bitumen absorbed by the filler is greater than the amount absorbed by fine and coarse aggregate grains. Thus, the impact of mastic on the properties of the asphalt mixture is much greater than the impact of the bitumen itself. This means that the critical level of the filler/bitumen concentration is the basis for the determination of the minimum amount of bitumen that ensures that the mastic in the diluted state can properly coat coarse aggregate grains [16]. The stiffness of the mastic may be affected not only by the concentration of the filler but also by the chemical composition of the filler itself and by the chemical composition of the bitumen [2], [17], which has a significant impact on the formation of adsorbentsolvate liquid layers with various thickness different from the liquid located farther away from the surface [18]. Due to increasing road traffic loading and the need to take into account environmental aspects, innovative materials and technologies should be considered. In this context, the interest in the warm mix asphalt (WMA) technology keeps increasing [19]. The WMA technology involves the compaction of asphalt mixtures at temperatures ranging from $100^{\circ} \mathrm{C}$ to $140^{\circ} \mathrm{C}$, which requires using modifiers [20], [21]. Although there are certain summaries of the impact of F-T synthetic wax on 
the properties of bitumen and asphalt mixtures [22], there is no exhaustive information about the impact of wax on the mastic. Consequently, this paper considers the use of synthetic wax in modelling of the critical concentration of mixed filler in the mastic.

\section{Materials and testing methods}

\subsection{Bitumen modified with F-T synthetic wax}

$50 / 70$ paving bitumen was used in the tests. Due to the small difference in density between bitumen and synthetic wax, synthetic wax was added to the asphalt in amounts of $1.5 \%$ and $3.0 \%$ by weight. The preparation process involved sampling of bitumen for each modification level, in the amount of $250 \mathrm{~g}$. The sample was subsequently heated up to $155^{\circ} \mathrm{C}$ and kept at that temperature for 30 minutes. The next stage was to mix the bitumen with synthetic wax. In order to ensure homogeneity, the binder was mixed in a blender at a constant temperature at $400 \mathrm{rpm}$. The main parameters of the produced wax/bitumen mixtures are presented in table 1 .

Table 1. Primary rheological parameters of $35 / 50$ bitumen modified with synthetic wax (W)

\begin{tabular}{|c|c|c|c|c|c|c|}
\hline \multirow{3}{*}{ Parameter } & \multirow{3}{*}{ Standard } & \multirow{3}{*}{ Unit } & \multicolumn{4}{|c|}{ Ingredient/mixture } \\
\hline & & & \multirow[b]{2}{*}{$\begin{array}{c}\text { Synthetic wax } \\
\text { (W) }\end{array}$} & \multirow{2}{*}{$\begin{array}{c}\begin{array}{c}\text { Asphalt } \\
\mathbf{5 0} / 70\end{array} \\
\mathbf{0 \%}\end{array}$} & \multicolumn{2}{|c|}{$\begin{array}{c}\text { Wax-modified } \\
\text { bitumen }\end{array}$} \\
\hline & & & & & $1.5 \% \mathrm{~W}$ & $3 \% \mathrm{~W}$ \\
\hline Softening temperature & PN-EN 1427:2015-0 & ${ }^{\circ} \mathrm{C}$ & 81 & 51.9 & 60.4 & 76 \\
\hline Penetration & PN-EN 1426:2015-08 & $0.1 \mathrm{~mm}$ & 9 & 58 & 42 & 31 \\
\hline $\mathrm{G}^{*} / \sin \delta$ at $60^{\circ} \mathrm{C}$ & NCHRP REPORT 459 & ${ }^{\circ} \mathrm{C}$ & - & 717 & 1725 & 3541 \\
\hline $\mathrm{Jnr} 3200 \mathrm{~Pa}$ at $60^{\circ} \mathrm{C}$ & PN-EN 16659:2016-02 & $\mathrm{kPa}^{-1}$ & - & 0.55 & 0.42 & 0.12 \\
\hline Fraass temperature & PN-EN 12593:2015-08 & ${ }^{\circ} \mathrm{C}$ & - & -10 & -9 & -7 \\
\hline Density at $25^{\circ} \mathrm{C}$ & PN-EN 15326+A1:2010 & $\mathrm{Mg} / \mathrm{m}^{3}$ & 0.97 & 1.030 & 1.029 & 1.028 \\
\hline
\end{tabular}

\subsection{Mixed filler}

The experiment involved using a reference limestone filler (LM) and mixed filler produced by combining hydrated lime (HL) and limestone filler in the ratio (HL/LM) of 0.15 and $0.3(\mathrm{~m} / \mathrm{m})$, in accordance with the recommendations of study [7]. Due to the different density of both ingredients, the volume fraction of hydrated lime (HL) in the limestone filler was within the range of $17.6 \%$ to $34.2 \%(\mathrm{v} / \mathrm{v})$. The filler was dried at $105^{\circ} \mathrm{C}$ for $24 \mathrm{~h}$ in order to eliminate moisture. Then, the filler was added to bitumen heated up to $120^{\circ} \mathrm{C}$ and constantly mixed at $500 \mathrm{rpm}$ for $10 \mathrm{~min}$. The detailed summary of results required by EN 14043 is presented in table 2 .

Table 2. Main physical and geometric parameters of mixed filler as per PN-EN 14043

\begin{tabular}{|c|c|c|c|c|c|}
\hline \multirow{2}{*}{$\begin{array}{c}\text { Paramete } \\
\mathbf{n}\end{array}$} & \multirow{2}{*}{ Standard } & Unit & \multicolumn{3}{|c|}{ Ingredient/mixture } \\
\cline { 4 - 6 } & & $\mathbf{L S}$ & \multicolumn{2}{|c|}{ HL/LS } \\
\cline { 4 - 6 } & & & $\begin{array}{c}\mathbf{0 . 1 5} \\
\mathbf{( m / m )}\end{array}$ & $\begin{array}{c}\mathbf{0 . 3} \\
\mathbf{( m / m )}\end{array}$ \\
\hline $\begin{array}{c}\text { Rigden } \\
\text { voids }\end{array}$ & $\begin{array}{c}\mathrm{EN} \\
1097-4\end{array}$ & $\%$ & 35.12 & 39.04 & 41.13 \\
\hline$\Delta \mathrm{T}_{\mathrm{R} \& \mathrm{~B}}$ & $\begin{array}{c}\mathrm{EN} \\
13179-1\end{array}$ & ${ }^{\circ} \mathrm{C}$ & 11.08 & 15.93 & 18.51 \\
\hline $\begin{array}{c}\text { Filler } \\
\text { compositi } \\
\text { on } \\
\text { particle } \\
\text { density }\end{array}$ & $\begin{array}{c}\mathrm{EN} \\
1097-7\end{array}$ & $\begin{array}{c}\mathrm{Mg} / \\
\mathrm{m}^{3}\end{array}$ & 2.71 & 2.63 & 2.55 \\
\hline $\begin{array}{c}\text { Specific } \\
\text { surface } \\
\text { area }\end{array}$ & $\begin{array}{c}\mathrm{EN} \\
196-6\end{array}$ & $\begin{array}{c}\mathrm{cm}^{2} / \\
\mathrm{g}\end{array}$ & 76363 & 81403 & 94652 \\
\hline
\end{tabular}

Excessive amount of hydrated lime in relation to the volume of the limestone filler should be avoided due to the intensive increase of mastic stiffness and significant reduction of the workability of the asphalt mixture [10]. The results of specific surface area measurement indicate that an increase of the HL/LS ratio will reduce the amount of free bitumen in the mastic.

\subsection{Dynamic modulus $\left|G^{*}\right|$ and phase angle $\delta$}

Dynamic tests were carried out using the Rheotest 4.1 rheometer in the oscillation mode. The tests were conducted using the "parallel plate" setup with the plate having a diameter of $25 \mathrm{~mm}$ and $1 \mathrm{~mm}$ gap between them. The stress amplitude was selected so as to conduct the test in the linear visco-elasticity region for the applied temperature range, and it was $>50 \mathrm{~Pa}$, establishing the LVE range [23]. All tests conformed to EN 14770:2012.

\section{Modelling the critical filler/bitumen concentration}

\subsection{Visco-elastic properties of the mastic composition}

The first stage of the tests of mastic properties was to determine the visco-elastic character of the mastic in the LVE range. The tests were limited to three temperatures, i.e. $40^{\circ} \mathrm{C}, 60^{\circ} \mathrm{C}, 80^{\circ} \mathrm{C}$, and to the frequency range of the 
applied shear stress from $0.01 \mathrm{~Hz}$ to $10 \mathrm{~Hz}$. Based on the references [8], [24], it was found that the dynamic modulus of the mastic for low temperature/short loading time approached the asymptotic value regardless of filler type. Consequently, the bitumen structuring effect of the filler would be most noticeable at temperatures over $40^{\circ} \mathrm{C}$. Also, evaluation of the increase in filler stiffness

a)

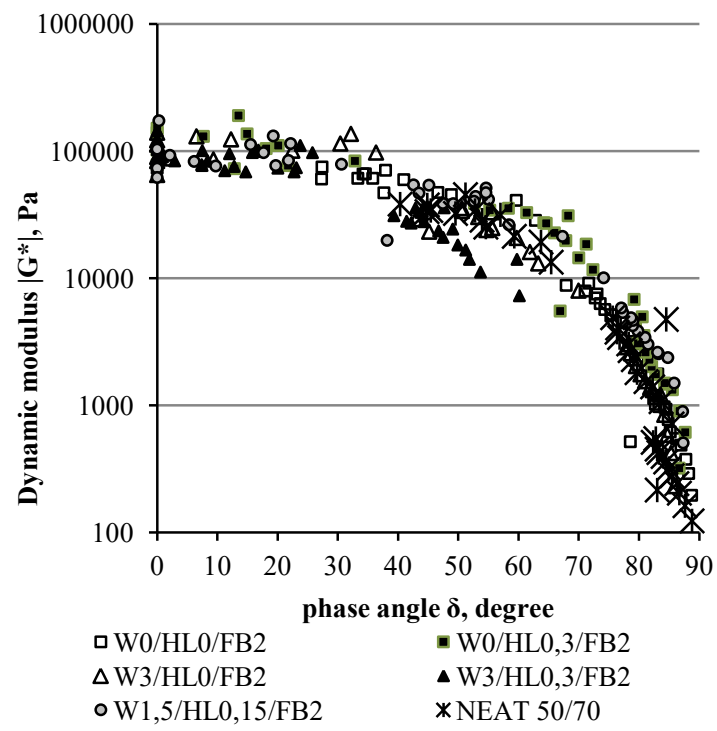

in the specific temperature range will demonstrate stiffness changes in the mastic and, potentially, in the asphalt mixture in which the mastic is an integral part. Also, such temperature level simulated the maximum temperature of the asphalt mixture in the summer season. The adopted form of representation of the results of stiffness $\mathrm{G}^{*}$ was the Black chart (Figure 1).

b)

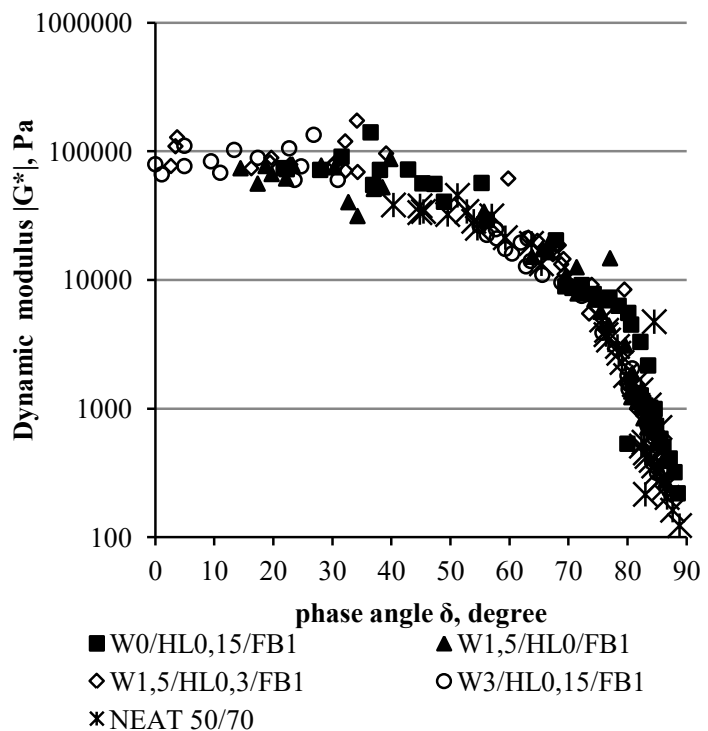

Figure. 1. Black curve: a) mastic compositions at $\mathrm{f} / \mathrm{b}=2 ; \mathrm{b}$ ) mastic compositions at $\mathrm{f} / \mathrm{b}=1$

Figure 1a presents the selected extreme mastic compositions with respect to the amount of synthetic wax (W) and content of hydrated lime in the filler (HL). It should be noted that ratio $\mathrm{f} / \mathrm{b}=2$ was close to the critical value [24]. Consequently, the rheological changes of stiffness would be strongly emphasised. With high content of the $\mathrm{W}$ and HL ingredients, mastic behaved as a body with significant elastic dominance of dynamic modulus $\left|G^{*}\right|$. The maximum phase angle was definitively the lowest in comparison to other mastic compositions. This composition was characterised by results grouped around the asymptotic value of $\left|G^{*}\right|$, equalling approximately $1 \times 10^{5} \mathrm{~Pa}$. This value is several dozen times higher than the stiffness of 50/70 bitumen. The results on the Black chart for the mastic consisting of conventional filler were strongly shifted towards high phase angle, and this mastic had slightly lower $\left|G^{*}\right|$ results. The results in figure $1 \mathrm{~b}$, in turn, selected out of the compositions with ratio $\mathrm{f} / \mathrm{b}=1$, present similar characteristics to figure $1 \mathrm{a}$ - the difference lies in the lower discrepancies between the results. This indicated small impact of filler composition on the bitumen, and it confirms that this mastic was in the diluted state. Nevertheless, the amount of wax was the main reason why some results of mastic stiffness had a low phase angle, suggesting the elastic character of the mastic.

\subsection{Conceptual regression model}

Considering the impact of hydrated lime on mastic properties, using the limestone filler (LM) and hydrated lime (HL) has a significant impact on the properties of the asphalt mixture made with such filler. Based on the experiences of the authors of publications [20], adding $1 \%$ to $1.5 \%$ of hydrated lime (of dry aggregate weight) improved the durability of the asphalt mixture by $2-10$ years, i.e. by approximately $20 \%$ to $50 \%$. Very extensive studies in the USA and numerous European studies conclusively demonstrate the beneficial impact of hydrated lime on the durability of the asphalt mixture [26]. For instance, in France and in the Netherlands, it was found that the presence of hydrated lime used for the wearing courses increased their durability by $20 \%-25 \%$ [7].

In the references, there were many attempts at determining the critical filler/bitumen concentration. It was established that the critical amount of the filler was the volume of compacted filler $\mathrm{V}_{\mathrm{fb}}$ (volume of compacted filler with pores) in the 55-60\% range [24]. An interesting alternative is the evaluation of the critical $\mathrm{f} / \mathrm{b}$ ratio by measuring the relative value of dynamic modulus $\left|\mathrm{G}^{*}\right|$. A function determining the critical $\mathrm{f} / \mathrm{b}$ ratio at measuring temperature of $60^{\circ} \mathrm{C}$ was proposed in the analysis of test results. This study proposes a slightly different method of determining the critical $f / b$ ratio, using a function combining two linear functions with a parabolic function. With five parameters, it can be generalised into the form of segmented regression [27]. Increase of dynamic modulus $\left|G^{*}\right|$ in relation to the value of 50/70 bitumen was used as the explanatory variable. The final form of the proposed spline indicating the change in mastic stiffness $\left(\left|\mathrm{G}^{*}\right|\right.$ Ratio $)$ is presented below (1): 
$\left|G^{*}\right| \operatorname{Ratio}\left(\frac{f}{b}\right)=\alpha_{0}+\alpha_{1} \cdot \frac{f}{b}+\frac{\alpha_{2}}{2} \cdot\left(\frac{f}{b}-C_{f / b}\right)+\alpha_{2}$.

$\sqrt{\frac{\left(\frac{f}{b}-C_{f / b}\right)^{2}}{4}+\exp \left(\alpha_{3}\right)}$

where: $\alpha_{0}-\alpha_{4}$ experimental parameters of the regression function, $C_{f / b}-$ critical $\mathrm{f} / \mathrm{b}$ ratio $(\mathrm{w} / \mathrm{w}), \mathrm{f} / \mathrm{b}-$ filler/bitumen ratio $(\mathrm{w} / \mathrm{w})$.

Parameter $\alpha_{4}$ smoothed the transition between two segments of linear functions. In the situation where $\alpha_{4} \rightarrow-\infty$, the function resembles a standard segmented function. The above model enabled very accurate representation of the changes in mastic stiffness vs. $f / b$ ratio in accordance with the conceptual model provided by Faheem et al. [2] and Stefańczyk et al [18]. Its graphic representation is presented below (Figure 2).

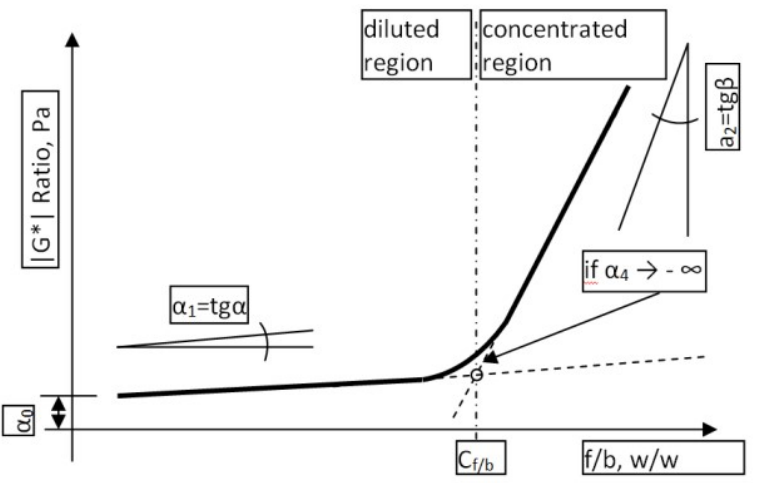

Figure. 2. Model of mastic stiffness change vs. filler concentration

The concept of the search for critical ratio $C_{f / b}$ assumes the existence of two ranges. The first of these is the $f / b$ range where the filler is dispersed in the mastic, demonstrating a diluted condition. The second range describes the state of mastic stiffening caused by the filler, where the filler particles mutually interact (concentrated). It should be noted that parameters a1 and $\mathrm{a}_{2}$ describing the change in mastic stiffness below and above the estimated critical value can be defined as the result of the derivative determined for the initial and final value of the $f / b$ ratio. This was related to the property of function (1), which was linear for the initial and final values. Parameter $\alpha_{1}$ represents the change in stiffness in the situation where the mastic is in the diluted state, i.e. when the amount of free bitumen dominates in the mastic volume. Parameter $\alpha_{2}$, in turn, defined the state where the increase in stiffness represented the range where the filler was characterised by excessive stiffness. It should also be noted that the form of the function was monotonic. Consequently, the physical and chemical properties of bitumen could be functionally associated with fillers of various compositions in a global manner. The rate of increase before and after exceeding critical ratio $c_{f / b}$ was expressed with the following formula (2):

$$
\frac{d\left(\left|G^{*}\right| \text { Ratio }\right)}{d\left(\frac{f}{b}\right)}=\alpha_{1}+\frac{\alpha_{2}}{2}-\frac{\alpha_{2} \cdot\left(\frac{c_{f}}{\left.\frac{b}{2}-\frac{f}{b}\right)}\right.}{2 \cdot \sqrt{e^{\alpha_{4}+\frac{\left(c_{f}-\frac{f}{b}\right)^{2}}{4}}}}
$$

where: $\alpha_{1}$ - inclination of the line in the diluted area of the mastic, $\alpha_{2}$-additional inclination of the line of the model after passing critical area $\mathrm{C}_{\mathrm{f} / \mathrm{b}}, \mathrm{C}_{\mathrm{f} / \mathrm{b}}-$ critical concentration of the filler in the mastic (w/w), $\alpha_{3}$ - nonlinear coefficient (combination of two lines with a hyperbolic function), $\mathrm{f} / \mathrm{b}$ - filler-to-mastic ratio (w/w).

\subsection{Test results}

Tests designed to describe changes in the dynamic modulus $\left|G^{*}\right|$ of the mastic were carried out for bitumen with 50/70 penetration modified with two levels of synthetic wax (SW) $-1.5 \%$ and $3 \%-$ at $60^{\circ} \mathrm{C}$. The test involved a mixed filler being a composition of hydrated lime (HL) and limestone dust (LM) in the amount (HL/LM) of $0.3(\mathrm{w} / \mathrm{w})$. The percentage of the $\mathrm{f} / \mathrm{b}$ ratio was $0.5 ; 1.0 ; 1.5 ; 2.0 ; 2.5$ and $3.0(\mathrm{w} / \mathrm{w})$. The average value was determined based on the median of the range between two results of the determination. The results of the fitting of the conceptual model to the experimental values including the result of the root-mean-square error (RMSE) of the estimation are presented in table 3.

Table 3. Estimation of model parameters in relation to $\left|\mathrm{G}^{*}\right|$ Ratio

\begin{tabular}{|c|c|c|c|c|c|c|c|}
\hline $\begin{array}{c}\text { Mastic composition } \\
\mathrm{W} / \frac{H L}{L M}\end{array}$ & \multicolumn{6}{|c|}{ Parameters of model $(1)$ for $\frac{f}{b}\{0.5 ; 1.0 ; 1.5 ; 2.0 ; 2.5 ; 3.0\}(\mathrm{w} / \mathrm{w})$} \\
\cline { 2 - 8 } & $\alpha_{0}$ & $\alpha_{1}$ & $\alpha_{2}$ & $\alpha_{3}$ & $C_{f / b}$ & $\mathrm{R}^{2}$ & $\begin{array}{c}\mathrm{RMS} \\
\mathrm{E}\end{array}$ \\
\hline $0 / 0$ (reference) & 1 & 1.03 & 6.38 & -259 & 2.27 & 0.98 & 0.2 \\
\hline $0 / 0.15$ & 1 & 2.72 & 19.91 & -259 & 2.27 & 0.98 & 0.5 \\
\hline $0 / 0.30$ & 1 & 7.20 & 44.8 & -259 & 2.27 & 0.98 & 2.7 \\
\hline $1.5 / 0$ & 2.4 & 2.84 & 17.67 & -259 & 2.27 & 0.98 & 0.5 \\
\hline $1.5 / 0.15$ & 2.4 & 4.85 & 35.70 & -259 & 1.94 & 0.97 & 2.8 \\
\hline $1.5 / 0.3$ & 2.4 & 19.93 & 124.04 & -259 & 2.27 & 0.98 & 3.3 \\
\hline $3 / 0$ & 4.9 & 5.07 & 37.31 & -259 & 1.94 & 0.98 & 3.0 \\
\hline $3 / 0.15$ & 4.9 & 20.83 & 129.62 & -259 & 2.27 & 0.98 & 8.1 \\
\hline $3 / 0.3$ & 4.9 & 55.18 & 170.43 & -259 & 1.93 & 0.98 & 20.8 \\
\hline
\end{tabular}


It should be noted that critical value $\mathrm{C}_{\mathrm{f} b \mathrm{~b}}$ was similar for different bitumen composition, and it approximated $2.3(\mathrm{w} / \mathrm{w})$ or $47.3(\mathrm{v} / \mathrm{v})$. Particularly in the situation where the mastic composition contained a large amount of synthetic wax and filler, critical value $\mathrm{C}_{\mathrm{f} / \mathrm{b}}$ was approximately $1.94(\mathrm{w} / \mathrm{w})$ or $43.1(\mathrm{v} / \mathrm{v})$. Estimation errors were small, and they were evaluated in the context of the low RMSE and high coefficient of determination $R^{2}$. During estimation of the function, parameter $\alpha_{3}=-259$ was adopted because this value made the effect of nonlinear transition between two lines unnoticeable.

Upon analysis of the test results (table 3 ), it should be emphasised that the increase of the amount of hydrated lime and synthetic wax resulted in an increase of the stiffness increase rate defined as $\alpha 1$. The greater the amount of synthetic wax, the quicker the increase of $\left|\mathrm{G}^{*}\right|$

a)

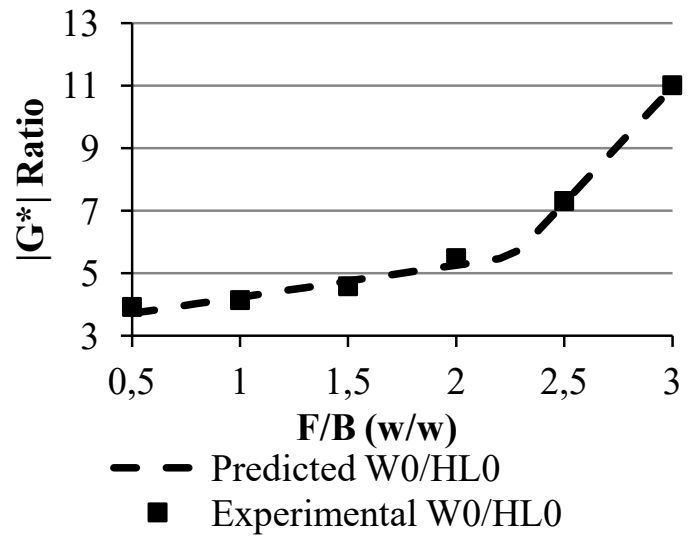

Ratio in the evaluation of parameters $\alpha_{1}$ and $\alpha_{2}$. This suggests a strong correlation between $\mathrm{W}$ and HL. This observation confirms the hypothesis that synthetic wax at the operating temperature of $60^{\circ} \mathrm{C}$ should be regarded as fine-crystalline filler [26]. Another interesting observation was the $\left|\mathrm{G}^{*}\right|$ Ratio result, which indicated that substituting the amount of $0.15 \mathrm{HL}$ produced the same increase of stiffness as $1.5 \%$ of synthetic wax. However, the increase of the amount of $\mathrm{W}$ resulted in the dependence of the base stiffness of the bitumen on the amount of synthetic wax, as demonstrated by the values of $\alpha_{0}$. In order to illustrate the changes in mastic stiffness, the figure below (Figure 3) presents the experimental results complete with a fitted function for three cases: $0 \mathrm{~W} / 0 \mathrm{HL}, 1.5 \mathrm{~W} / 0,15 \mathrm{HL}$ and $3 \mathrm{~W} / 0.3 \mathrm{HL}$.

b)

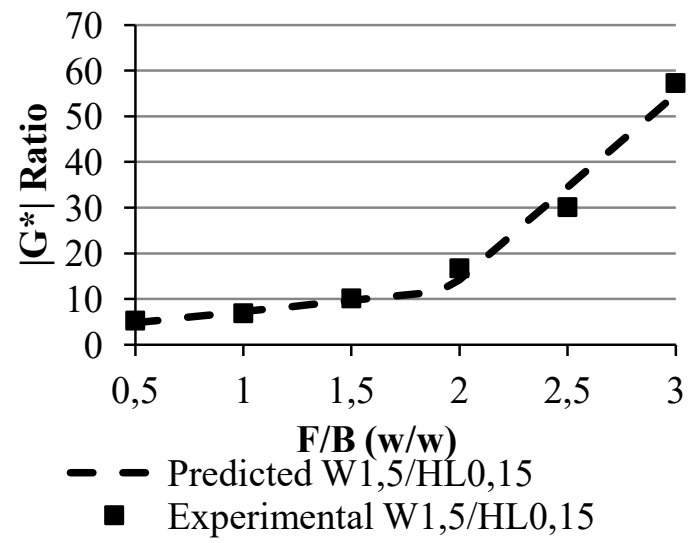

c)

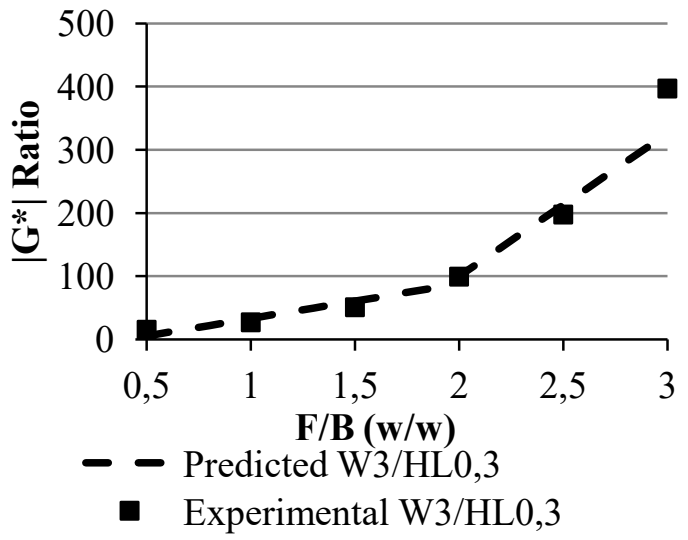

Figure 3. Increase of stiffness in relation to the value of f/b: a) W0/HL0; b) W1.5/HL0.15 c) W3.0/HL0.3

It should be noted that higher concentration of $\mathrm{W}$ and HL increased the rate at which mastic stiffness increased. As mentioned earlier, the rate of stiffness increase is affected by the interaction between $\mathrm{W}$ and HL. This can be observed by comparing the rate of increase of the factors in relation to the reference value of $0 \mathrm{~W} / 0 \mathrm{HL}$. For the $1.5 \mathrm{~W} / 0.15 \mathrm{HL}$ composition, the increase of parameter $\alpha 1$ is 4.7 , whereas for $\alpha_{2}$ the increase is 5.6. For $3 \mathrm{~W} / 0.3 \mathrm{HL}$, the increase of parameter $\alpha_{1}$ is 53.5, whereas for $\alpha_{2}$, respectively -26.7 . Also, critical value $\mathrm{C}_{\mathrm{f} / \mathrm{b}}$ was reduced from 2.7 to $1.93(\mathrm{w} / \mathrm{w})$ after adding ingredients $\mathrm{W}$ and HL, which was the direct result of the hydrated lime binding a greater amount of free bitumen. Consequently, the amount of bitumen added to the mastic has to be increased to ensure suitable workability of the asphalt mixture by maintaining mastic properties in the diluted state. 
Further important observations can be drawn from a comparison of the stiffness achieved by reference mastic $0 \mathrm{~W} / 0 \mathrm{HL}$ in relation to $1.5 \mathrm{~W} / 0.15 \mathrm{HL}$ and $3 \mathrm{~W} / 0.3 \mathrm{HL}$ compositions. The increase of stiffness caused by the use of conventional filler with its critical value $\mathrm{C}_{\mathrm{f} / \mathrm{b}}=2.27$ can be achieved with ratio $\mathrm{f} / \mathrm{b}<1$ for the remaining above-mentioned mastic compositions. Consequently, the amount of bitumen required to produce mastic with properties comparable to those of the reference mastic will be much greater. Therefore, achieving the critical value on the level of the reference mastic will result in a significant increase of the stiffness of the asphalt mixture, particularly at the bottom limit of the temperature at the end of compaction of the asphalt mixture, i.e. approximately $90^{\circ} \mathrm{C}$. Still, leaving the amount of the filler required to provide the stiffness in relation to the reference mastic would increase the amount of free bitumen, which may have a positive effect on the operating properties of the mixture if suitable resistance to plastic deformation is ensured.

\section{Conclusions}

The tests and analysis of different mastic compositions support the following conclusions:

- the proposed form of the conceptual regression model very adequately describes the changes relating to mastic stiffness increase. The parameters used in the model together describe mastic behaviour both in the diluted range and after exceeding critical value $\mathrm{C}_{\mathrm{f} / \mathrm{b}}$;

- there is an interaction between ingredients $\mathrm{W}$ and HL, which significantly affects the rate of mastic stiffness increase. This proves the hypothesis that synthetic wax at operating temperatures acts as a fine filler;

- the increase of the amounts of $\mathrm{W}$ and HL reduces critical value $\mathrm{C}_{\mathrm{f} / \mathrm{b}}$. Consequently, this fact should be considered when designing the asphalt mixture;

- the amount of unabsorbed bitumen in the mastic is two times greater if $\mathrm{W}$ and $\mathrm{HL}$ are used than in the composition with conventional LM filler.

- using the critical concentration of the HL/LM mixed filler with synthetic wax should be avoided because mastic will be in the elastic state (low phase angle) at temperatures close to $90^{\circ} \mathrm{C}$. The elastic dominance of modulus $\left|G^{*}\right|$ will hinder the compaction of the mixture.

- it was found that hydrated lime in the amount of 0.15 $(\mathrm{w} / \mathrm{w})$ resulted in an increase of stiffness similar to the use of synthetic wax in an amount of $1.5 \%(\mathrm{w} / \mathrm{w})$ in the bitumen.

\section{Acknowledgments}

The research results were developed as part of the project entitled " The innovative technology used the binding agent optimization that provides the long service life of the recycled base course" within the scientific undertaking of Strategic Research and Development Program entitled "Modern Materials Technology"
(TECHMATSTRATEG I), which is financed by the National Center for Research and Development (NCBiR).

\section{References}

[1] M. Zeng i C. Wu, „Effects of Type and Content of Mineral Filler on Viscosity of Asphalt Mastic and Mixing and Compaction Temperatures of Asphalt Mixture", Transportation Research Record: Journal of the Transportation Research Board, $\mathrm{t}$. 2051, s. 31-40, grudz. 2008.

[2] A. F. Faheem i H. U. Bahia, ,Modelling of Asphalt Mastic in Terms of Filler-Bitumen Interaction", Road Materials and Pavement Design, t. 11, nr sup1, s. 281-303, sty. 2010.

[3] D. A. Anderson i W. H. Goetz, ,Mechanical Behavior and Reinforcement of Mineral FillerAsphalt Mixtures", Journal of the Association of Asphalt Paving Technologists, t. 42, s. 37-66, 1977.

[4] W. Grabowski i J. Wilanowicz, ,The structure of mineral fillers and their stiffening properties in filler-bitumen mastics", Materials and Structures, t. 41, nr 4, s. 793-804, maj 2008.

[5] J. Pilat, Wpływ właściwości maczek mineralnych na ksztattowanie cech technicznych kompozytów mineralno-asfaltowych. Warszawa: Oficyna Wydawnicza Politechniki Warszawskiej, 1994.

[6] J. Pilat, P. Radziszewski, i M. Kalabińska, „The analysis of visco-elastic properties of mineralasphalt mixes with lime and rubber powder", zaprezentowano na Proceedings of the papers submitted for review at 2nd Eurasphalt and Eurobitume Congress, book 1 - session 1, Barcelona, Spain, 2000, s. 648-654.

[7] D. Lesueur, J. Petit, i H.-J. Ritter, „The mechanisms of hydrated lime modification of asphalt mixtures: a state-of-the-art review", Road Materials and Pavement Design, t. 14, nr 1, s. 116, mar. 2013.

[8] B. Delaporte, H. Di Benedetto, P. Chaverot, i G. Gauthier, „Linear Viscoelastic Properties of Bituminous Materials Including New Products Made with Ultrafine Particles", Road Materials and Pavement Design, t. 10, nr 1, s. 7-38, sty. 2009.

[9] G. Mazzoni, A. Stimilli, F. Cardone, i F. Canestrari, ,Fatigue, self-healing and thixotropy of bituminous mastics including aged modified bitumens and different filler contents", Construction and Building Materials, t. 131, s. 496-502, sty. 2017.

[10] R. Miró, A. H. Martínez, F. E. Pérez-Jiménez, R. Botella, i A. Álvarez, „Effect of filler nature and content on the bituminous mastic behaviour under cyclic loads", Construction and Building Materials, t. 132, s. 33-42, luty 2017.

[11] M. Iwanski i G. Mazurek, ,The effect of hydrated lime on the rheological properties of extracted 
bitumen from stone mastic asphalt", Cement Wapno Beton, t. R. 19/81, nr 6, s. 376-383, 2014.

[12] R. G. Hicks, ,Moisture damage in asphalt concrete". NCHRP synthesis of highway practice 175, Transportation Research Board, National Research Council, 1991.

[13] J. Pilat i P. Radziszewski, „Wapno hydratyzowane. Wpływ na właściwości mastyksów i betonów asfaltowych", Autostrady, nr 1-2, s. 58-62, 2006.

[14] J. Judycki i P. Jaskuła, „Badania odporności betonu asfaltowego zawierającego wapno hydratyzowane na działanie wody i mrozu", $V$ Międzynarodowa Konferencja Trwate $i$ Bezpieczne Nawierzchnie Drogowe, s. 111-118, maj 1999.

[15] P. Buczyński i M. Iwański, „Inactive Mineral Filler as a Stiffness Modulus Regulator in Foamed Bitumen-Modified Recycled Base Layers", IOP Conference Series: Materials Science and Engineering, t. 245, s. 032042, paź. 2017.

[16] S. Bressi, A. G. Dumont, i M. N. Partl, „An advanced methodology for the mix design optimization of hot mix asphalt", Materials \& Design, t. 98, s. 174-185, maj 2016.

[17] C. W. Curtis, K. Ensley, i J. Epps, „Fundamental Properties of Asphalt-Aggregate Interactions Including Adhesion and Absorption". SHRP-A341, National Academy of Science, USA, 1993.

[18] B. Stefańczyk i P. Mieczkowski, Mieszanki mineralno-asfaltowe: wykonawstwo i badania. Warszawa: Wydawnictwa Komunikacji i Łączności, 2009.

[19] M. Pasetto, A. Baliello, G. Giacomello, i E. Pasquini, „Rheological Characterization of WarmModified Asphalt Mastics Containing Electric Arc Furnace Steel Slags", Advances in Materials Science and Engineering, t. 2016, s. 1-11, 2016.

[20] M. Iwański i G. Mazurek, ,Structuring role of F-T synthetic wax in bitumen", Bulletin of the Polish Academy of Sciences Technical Sciences, t. 62, nr 3, sty. 2014.

[21] A. Chomicz-Kowalska, W. Gardziejczyk, i M. M. Iwański, „Moisture resistance and compactibility of asphalt concrete produced in half-warm mix asphalt technology with foamed bitumen", Construction and Building Materials, t. 126, s. 108-118, lis. 2016.

[22] A. Jamshidi, M. O. Hamzah, i Z. You, „Performance of Warm Mix Asphalt containing Sasobit $\AA$ : State-of-the-art", Construction and Building Materials, t. 38, s. 530-553, sty. 2013.

[23] D. H. Jung, Low temperature cracking: binder validation. Washington, DC, 1994.

[24] W. Grabowski, Struktura a właściwości funkcjonalne wypetniaczy mineralnych stosowanych $w$ drogownictwie. Poznań: Wydawnictwo Politechniki Poznańskiej, 2007.

[25] D. N. Little i J. C. Petersen, „Unique Effects of Hydrated Lime Filler on the Performance-Related Properties of Asphalt Cements: Physical and Chemical Interactions Revisited", Journal of
Materials in Civil Engineering, t. 17, nr 2, s. 207218, kwi. 2005.

[26] D. Lesueur, ,Hydrated lime: A proven additive for durable asphalt pavements - Critical literature review". Brussels: European Lime Association (EuLA), 2010.

[27] A. Stanisz i R. Tadeusiewicz, Przystępny kurs statystyki z zastosowaniem STATISTICA PL na przykładach z medycyny. T. 2, T. 2,. Kraków: StatSoft, 2007.

[28] H. M. R. D. Silva, J. R. M. Oliveira, J. Peralta, i S. E. Zoorob, „Optimization of warm mix asphalts using different blends of binders and synthetic paraffin wax contents", Construction and Building Materials, t. 24, nr 9, s. 1621-1631, wrz. 2010. 